\title{
Honeywell
}

\section{CHARACTERIZATION OF LITHIUM STEARATE: PROCESSING AID FOR FILLED ELASTOMERS}

Federal Manufacturing \& Technologies
E. A. Eastwood
C. Densmore

KCP-613-8264

February 2007

Final Report

Approved for public release; distribution is unlimited.

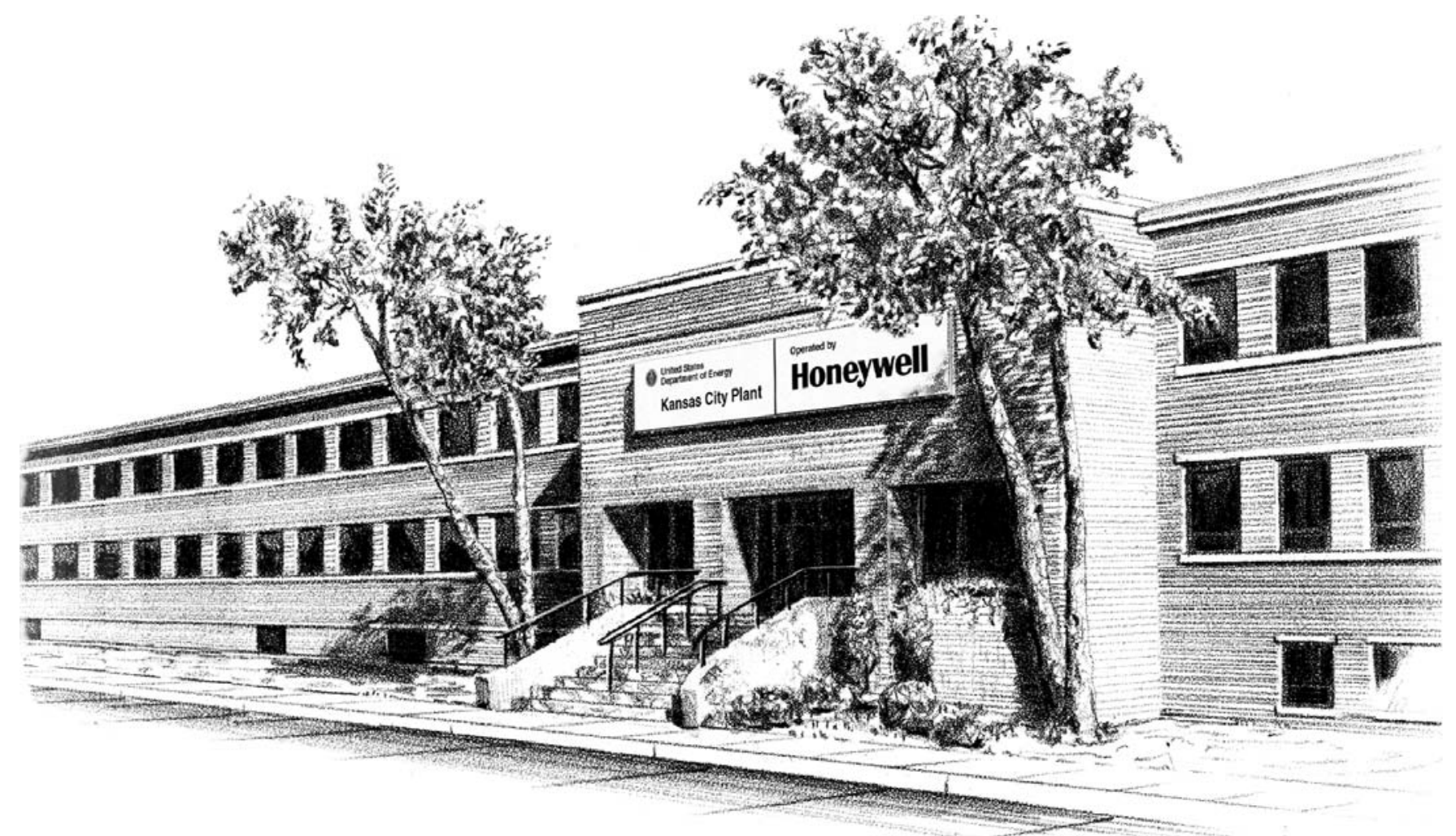

Prepared under prime contract DE-ACO4-01AL66850 for the United States Department of Energy 


\section{DISCLAIMER}

This report was prepared as an account of work sponsored by an agency of the United States Government. Neither the United States Government nor any agency thereof, nor any of their employees, makes any warranty, express or implied, or assumes any legal liability or responsibility for the accuracy, completeness, or usefulness of any information, apparatus, product, or process disclosed, or represents that its use would not infringe privately owned rights. Reference herein to any specific commercial product, process or service by trade names, trademark, manufacturer, or otherwise, does not necessarily constitute or imply its endorsement, recommendation or favoring by the United States Government or any agency thereof. The views and opinions of authors expressed herein do not necessarily state or reflect those of the United States Government or any agency thereof.

All data prepared, analyzed and presented has been developed in a specific context of work and was prepared for internal evaluation and use pursuant to that work authorized under the reference contract. Reference herein to any specific commercial product, process or service by trade name, trademark, manufacturer, or otherwise, does not necessarily constitute or imply its endorsement, recommendation or favoring by the United States Government, any agency thereof or Honeywell Federal Manufacturing \& Technologies, LLC.

Printed in the United States of America.

This report has been reproduced from the best available copy.

Available to DOE and DOE contractors from the Office of Scientific and Technical Information, P.O. Box 62, Oak Ridge, Tennessee 37831; prices available from (865) 576-8401, FTS 626-8401.

Available to the public from the National Technical Information Service, U.S. Department of Commerce, 5285 Port Royal, Rd., Springfield, Virginia 22161, (703) 487-4650.

A prime contractor with the United States Department of Energy under Contract Number DE-AC04-O1AL66850
Honeywell Federal Manufacturing \& Technologies P.O. Box 419159 Kansas City, Missouri, 64141-6159 


\title{
Honeywell
}

KCP-613-8264

Distribution Category UC-36

Approved for public release; distribution is unlimited.

\section{CHARACTERIZATION OF LITHIUM STEARATE:}

PROCESSING AID FOR FILLED ELASTOMERS

\author{
E. A. Eastwood \\ C. Densmore
}

February 2007

Final Report 


\section{Contents}

Section Page

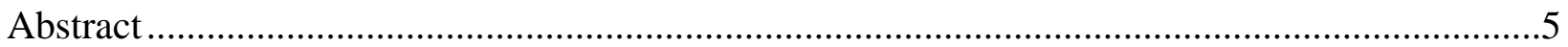

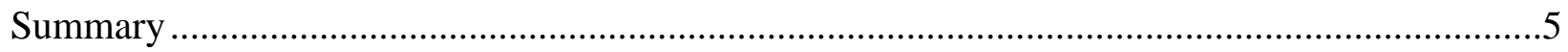

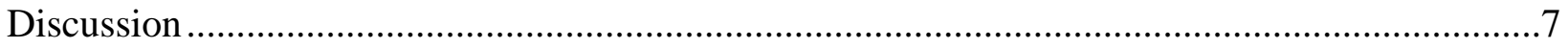

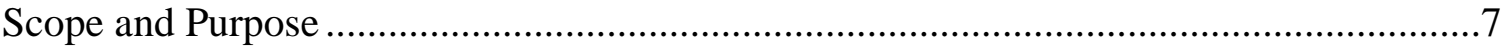

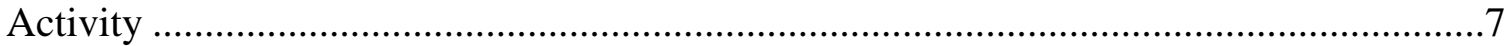

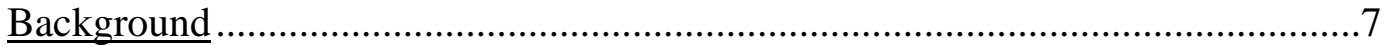

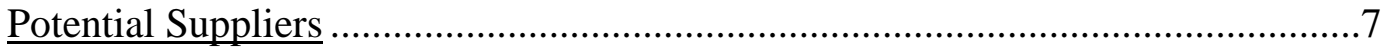

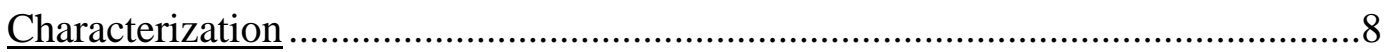

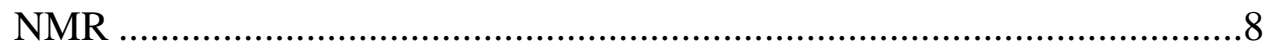

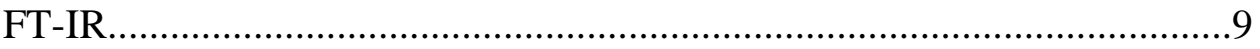

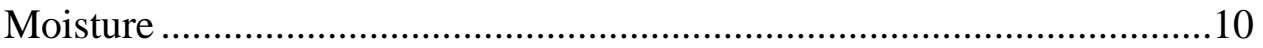

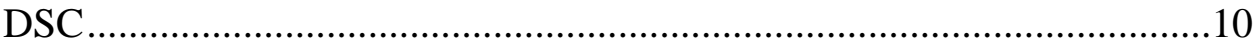

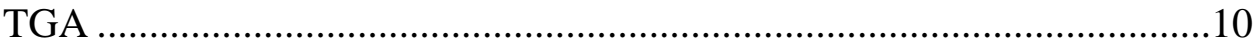

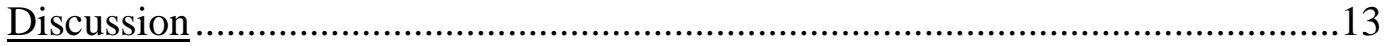

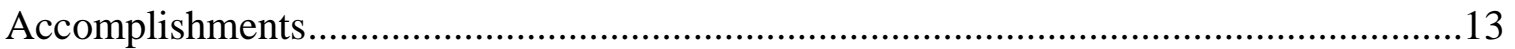

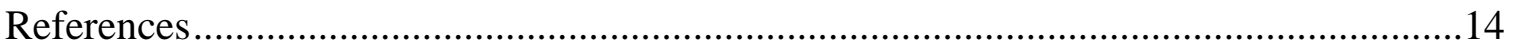




\section{Illustrations}

Figure Page

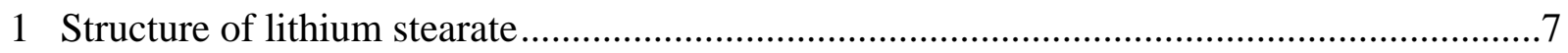

2 Transmission FT-IR spectra of lithium stearate samples prepared with $\mathrm{KBr}$. Spectra collected at $2 \mathrm{~cm}^{-1}$ resolution with 16 scans ....................................................9

3 First heat DSC curves for three lots of lithium stearate ...............................................11

4 Cool down DSC curves for three lots of lithium stearate ..............................................11

5 Second heat (reheat) DSC curves for three lots of lithium stearate ...................................12

6 TGA thermograms of the three lots of lithium stearate .................................................13

\section{Tables}

Table

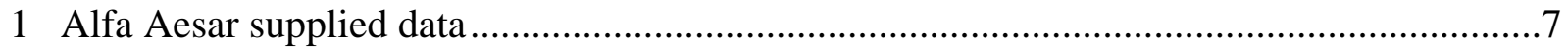

2 Initial characterization data from Chemtura ...............................................................8

3 Solvents assessed for lithium stearate......................................................................8

4 FT-IR peak identification for lithium stearate .........................................................9

5 Moisture data in ppm and weight \% for the three lithium stearates ...............................10

6 Peak transitions from DSC data for three lithium stearates ...........................................12 


\begin{abstract}
This topical report presents work completed to characterize lithium stearate so a replacement supplier could be identified. Lithium stearate from Alfa Aesar and Chemtura was obtained and characterized along with the current material from Witco. Multiple methods were used to characterize the materials including Karl Fischer, FT-IR, differential scanning calorimetry, and thermogravimetric analysis.
\end{abstract}

\title{
Summary
}

This report details characterization studies of lithium stearate. Lithium stearate is a lithium salt of stearic acid $\left(\mathrm{LiC}_{18} \mathrm{H}_{35} \mathrm{O}_{2}\right)$ and is used as a processing aid or lubricant during filled elastomer part production. Currently, lithium stearate from Witco is used in production; however, this material is no longer commercially available and an alternate, replacement supplier must be identified. Two replacement vendors that distribute technical grade lithium stearate were identified: Alfa Aesar and Chemtura (formerly Crompton Corporation). Several techniques were used to characterize the current material and material from the two replacement vendors. Solution NMR was attempted with numerous solvents; however, the analysis could not be completed due to the limited solubility of lithium stearate. The structure of the lithium stearate was confirmed with transmission FT-IR. The FT-IR spectra for two lots of the lithium stearate showed characteristic peaks associated with carboxylate and aliphatic C-H deformations. All three lots of lithium stearate were evaluated for moisture by Karl Fischer techniques and were found to have a very low amount of residual water. In addition, all three lots have very similar moisture values. The thermal properties were characterized using differential scanning calorimetry and thermogravimetric analysis for the lithium stearates. Again, all three lots of lithium stearates revealed similar thermal behavior. Alfa Aesar lithium stearate was chosen as the replacement material based on the container sizes available commercially. 
This Page is Intentionally Left Blank 


\section{Discussion}

\section{Scope and Purpose}

This study is a part of a project to characterize the starting materials used in filled elastomer part production. While other reports ${ }^{1-7}$ have detailed characterization of the other materials used for filled elastomer part production (ethylene/vinyl acetate/vinyl alcohol terpolymer called VCE and curing agent called Hylene MP), this report details work to characterize lithium stearate.

Currently, lithium stearate from Witco is used during production; however, this material is no longer commercially available and an alternate, replacement supplier must be identified. Once the lithium stearates have been well characterized, a replacement lithium stearate can be chosen to replace the current material being used.

\section{Activity}

\section{Background}

Lithium stearate is a processing aid or lubricant used during filled elastomer part production. ${ }^{8}$ Lithium stearate is the lithium salt of stearic acid $\left(\mathrm{LiC}_{18} \mathrm{H}_{35} \mathrm{O}_{2}\right)$ and shown in Figure 1. The CAS number for lithium stearate is 4485-12-5.

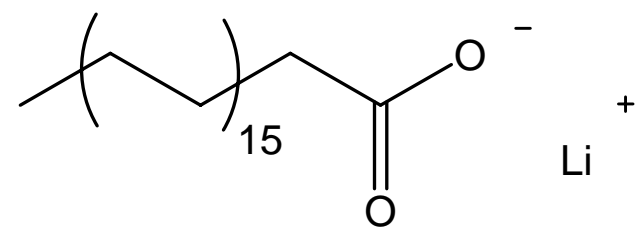

Figure 1: Structure of lithium stearate.

\section{Potential Suppliers}

Two replacement vendors that distribute technical grade lithium stearate were identified: Alfa Aesar and Chemtura (formerly Crompton Corporation). Item \#39335 (lot number G31M14) was purchased from Alfa Aesar and the following vendor data was supplied with the material.

Table 1: Alfa Aesar supplied data.

\begin{tabular}{|c|c|}
\hline Total Ash & $5.28 \%$ \\
\hline Moisture & $0.13 \%$ \\
\hline Free fatty acid & $0.36 \%$ \\
\hline Softening Point & $215^{\circ} \mathrm{C}$ \\
\hline Fineness through 325 mesh & $100 \%$ \\
\hline
\end{tabular}


Chemtura supplies a number of different grades of lithium stearates: 90A, 90B, 304, and 306. Due to availability, lithium stearate 306 with batch \# ME5K14M001 was obtained for evaluation. The data provided in Table 2 was supplied from Chemtura with the material:

Table 2: Initial characterization data from Chemtura.

\begin{tabular}{|c|c|}
\hline Alkalinity & $0.02 \%$ \\
\hline Moisture & $1.00 \%$ \\
\hline Free fatty acid & $0.00 \%$ \\
\hline Lithium Content & 2.50 \\
\hline Fineness through 200 mesh & $99.6 \%$ \\
\hline Fineness through 40 mesh & $100 \%$ \\
\hline
\end{tabular}

\section{Characterization}

NMR. An attempt was made to analyze and compare two samples of lithium stearate by ${ }^{1} \mathrm{H}$ NMR; one sample was the lithium stearate currently used in production (from Witco with lot number B3613190010001), and the other sample was the lot G31M14 from Alfa Aesar.

However, the extremely limited solubility of lithium stearate prevented analysis by solution NMR. The solubility of lithium stearate was assessed using the solvents listed in Table 3. At best, lithium stearate was slightly soluble in any of these solvents.

Table 3: Solvents assessed for lithium stearate.

\begin{tabular}{|l|}
\hline Solvent: \\
\hline Chloroform - $\mathrm{CHCl}_{3}$ \\
\hline Methylene Chloride $-\mathrm{CH}_{2} \mathrm{Cl}_{2}$ \\
\hline Carbon Tetrachloride - $\mathrm{CCl}_{4}$ \\
\hline Acetone \\
\hline Water \\
\hline Dimethylsulfoxide - DMSO \\
\hline n, n- Dimethylformamide - DMF \\
\hline Methanol - $\mathrm{CH}_{3} \mathrm{OH}$ \\
\hline Ethanol - $\mathrm{CH}_{3} \mathrm{CH}_{2} \mathrm{OH}$ \\
\hline Acetonitrile - $\mathrm{CH}_{3} \mathrm{CN}$ \\
\hline Tetrahydrofuran - THF \\
\hline Toluene \\
\hline Benzene \\
\hline n-Hexane \\
\hline
\end{tabular}


FT-IR. Because we could not find a solvent system suitable for lithium stearate, transmission FT-IR spectra of the two samples were collected. A potassium bromide (KBr) pellet was prepared for each sample. A Mattson 5000 FT-IR spectrometer was used for the analysis. Before spectra were collected, a background spectrum was collected and stored. All spectra were collected from $4000 \mathrm{~cm}^{-1}$ to $400 \mathrm{~cm}^{-1}$ with a resolution of $2 \mathrm{~cm}^{-1}$ and 16 scans (see Figure 2).

The transmission FT-IR spectra of the lithium stearate samples are very similar and both show characteristic peaks associated with carboxylate and aliphatic C-H deformations, as shown in Table 4.

Table 4: FT-IR peak identification for lithium stearate.

\begin{tabular}{|l|l|}
\hline Wavenumber $\mathbf{( c m}^{-\mathbf{1}} \mathbf{)}$ & Functional Group: \\
\hline $3000-2840$ & Aliphatic C-H stretching from $\mathrm{CH}_{3}$ and $\mathrm{CH}_{2}$ groups \\
\hline $1600-1550$ & Asymmetric (COO) ${ }^{-}$stretching from carboxylate group \\
\hline $1500-1400$ & $\begin{array}{l}\text { Multiple peaks arising from symmetric }(\mathrm{COO})^{-} \text {stretching from } \\
\text { carboxylate group and asymmetric C-H stretching from } \mathrm{CH}_{3} \\
\text { and } \mathrm{CH}_{2} \text { groups }\end{array}$ \\
\hline$* 750-700$ & $\mathrm{CH}_{2}$ deformation \\
\hline
\end{tabular}

*Other deformations associated with (COO) ${ }^{-}$can also occur below $800 \mathrm{~cm}^{-1}$.

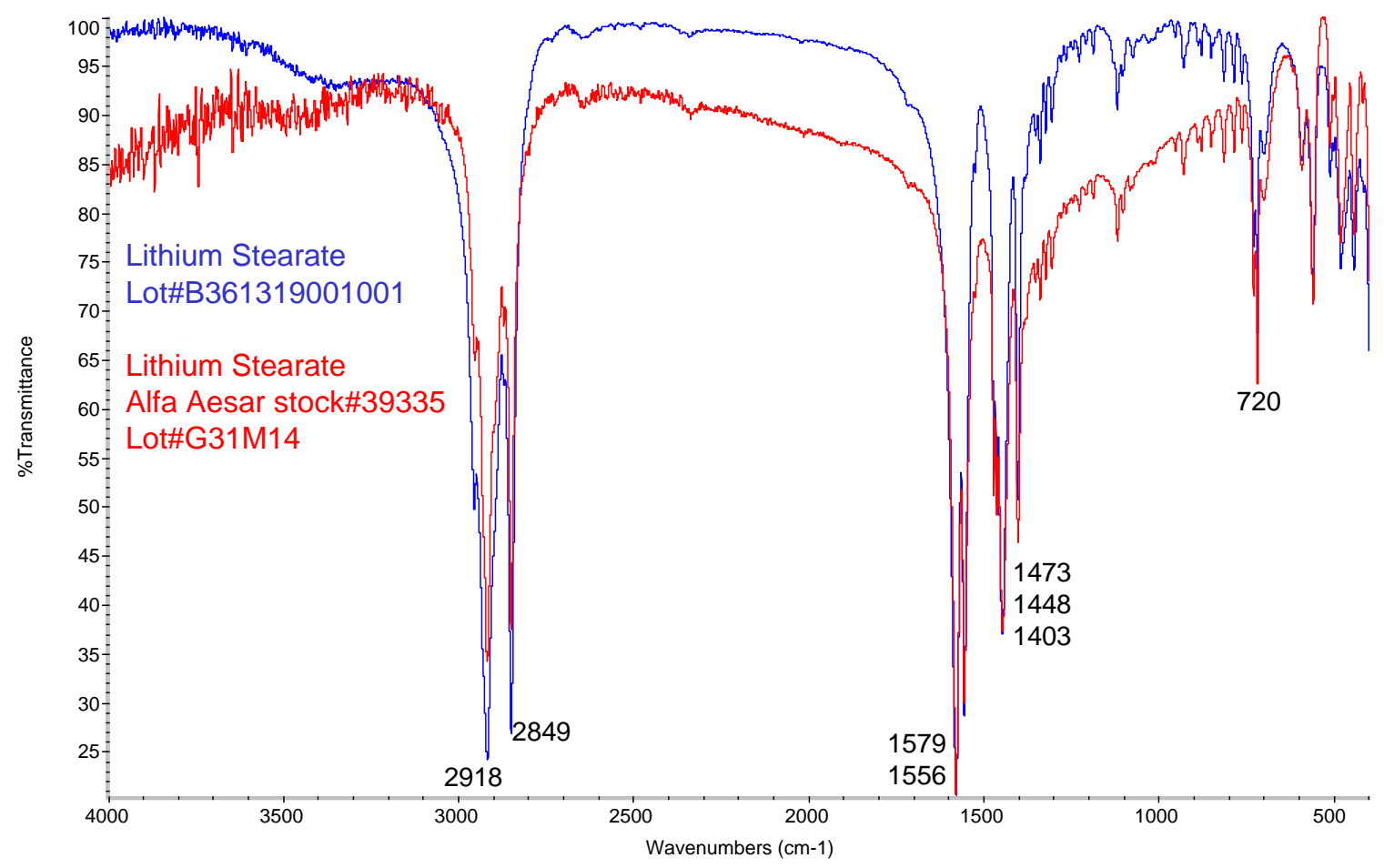

Figure 2. Transmission FT-IR spectra of lithium stearate samples prepared with $\mathrm{KBr}$. Spectra collected at $2 \mathrm{~cm}^{-1}$ resolution with 16 scans. 
Moisture. Moisture data were available for three lots (from Witco, Alfa Aesar, and Chemtura); however, it is unclear if the same methods were used for the data available. Therefore, all three lots of lithium stearate were re-tested for moisture using a Karl Fischer oven at $180^{\circ} \mathrm{C}$. The moisture data for the three lots tested are given below in Table 5. The Chemtura lithium stearate had a much lower value than reported from the manufacturer ( $0.019 \%$ vs. $1 \%)$. Generally, all of lithium stearates had comparable moisture contents ranging from 0.019 to $0.029 \%$.

Table 5: Moisture data in ppm and weight \% for the three lithium stearates.

\begin{tabular}{|c|c|c|c|}
\hline Vendor & Lot \# & $\begin{array}{c}\text { Water Content } \\
\text { (ppm) }\end{array}$ & $\begin{array}{c}\text { Water Content } \\
\mathbf{( \% )}\end{array}$ \\
\hline Witco & B3613190010001 & 293 & $.029 \%$ \\
\hline Alfa Aesar & G31M14 & 241 & $.024 \%$ \\
\hline Chemtura & ME5K14M001 & 188 & $.019 \%$ \\
\hline
\end{tabular}

DSC. Alkali metal stearates such as lithium stearate are reported in the literature to exhibit liquid crystalline behavior and have multiple phase transitions. ${ }^{9-15}$ Solid state crystalline transition from orthorhombic to hexagonal packing transition is reportedly expected to occur from $102{ }^{\circ} \mathrm{C}$ to $104{ }^{\circ} \mathrm{C}$. From $193{ }^{\circ} \mathrm{C}$ to $194{ }^{\circ} \mathrm{C}$, a transition from crystalline to rotational or crystalline state occurs. Finally, from $225^{\circ} \mathrm{C}$ to $228^{\circ} \mathrm{C}$ a melting transition is found. The three lots of lithium stearate from Witco, Alfa Aesar, and Chemtura, respectively, were analyzed using a TA Instruments Q1000 differential scanning calorimeter (DSC). Approximately 10-mg samples were placed in aluminum pans and heated from $25^{\circ} \mathrm{C}$ to $250{ }^{\circ} \mathrm{C}$ at $10^{\circ} \mathrm{C} / \mathrm{min}$ under a helium atmosphere, followed by cooling at the same rate to $0{ }^{\circ} \mathrm{C}$. The samples were then reheated a second time to $250^{\circ} \mathrm{C}$. The DSC profiles of these metal stearates are very dependent on the atmosphere under which it is heated. ${ }^{9}$ Under an inert atmosphere such as under nitrogen, helium, or argon, all three transitions are endothermic. However, if the sample is heating in air or oxygen, the two higher temperature transitions (at approximately $193{ }^{\circ} \mathrm{C}$ and $225^{\circ} \mathrm{C}$ ) become exothermic. The DSC profiles of all three lithium stearate samples obtained under helium are shown in Figures 3 through 5; the peak positions of the thermal transitions are listed in Table 6. All of the lithium stearates have very similar thermal behavior and peak positions were nearly identical.

TGA. Thermogravimetric analysis (TGA) was completed on the lithium stearates using a TA Instruments Q500 TGA. Approximately $10 \mathrm{mg}$ of each sample was heated from room temperature up to $600{ }^{\circ} \mathrm{C}$ at $10^{\circ} \mathrm{C} / \mathrm{min}$ and the corresponding change in weight percents are plotted as a function of temperature in Figure 6. These thermograms are quite similar to those reported in the literature under similar conditions. Under inert atmosphere the first degradation begins around $200{ }^{\circ} \mathrm{C}$, followed by an accelerated degradation above $400{ }^{\circ} \mathrm{C}$. The weight loss continues until approximately $530^{\circ} \mathrm{C}$ where approximately $10 \%$ weight/ash remains. According to the literature, lithium stearate first decomposes to lithium oxalate and then to carbonate at $550{ }^{\circ} \mathrm{C} .{ }^{9}$ Regardless, there are not many differences between the TGA thermograms and decomposition profiles for the three lots of lithium stearates. 


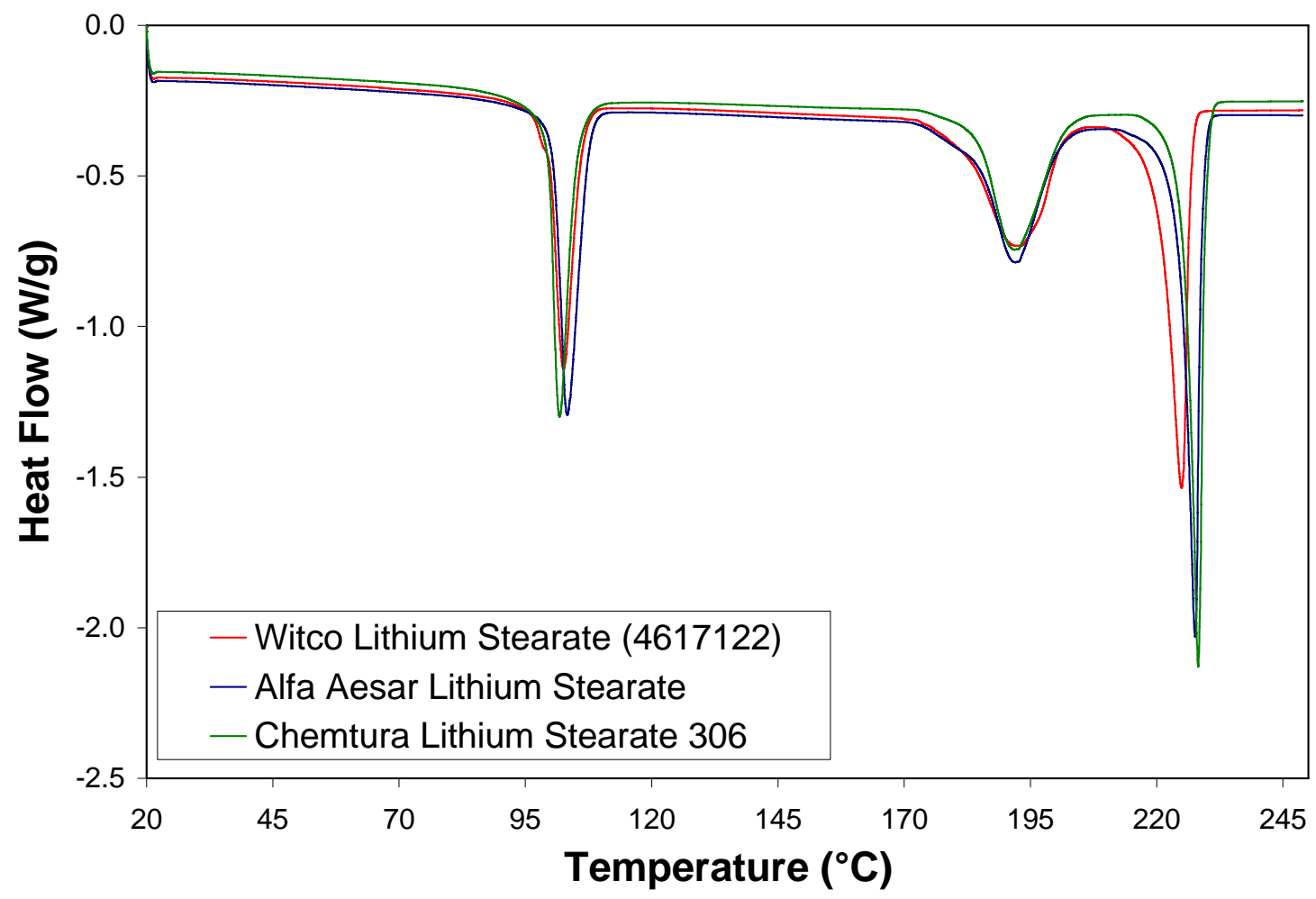

Figure 3. First heat DSC curves for three lots of lithium stearate.

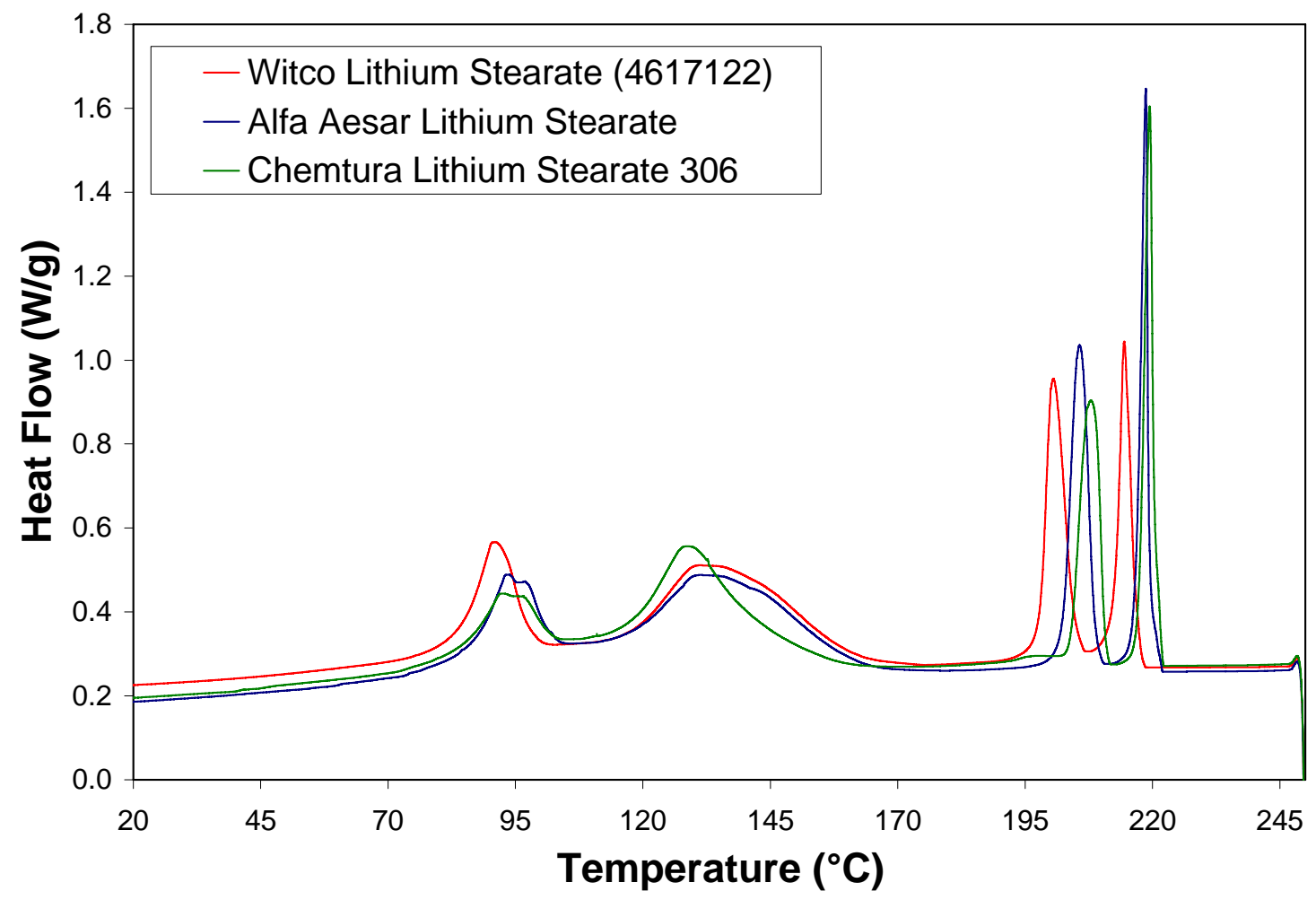

Figure 4. Cool down DSC curves for three lots of lithium stearate. 


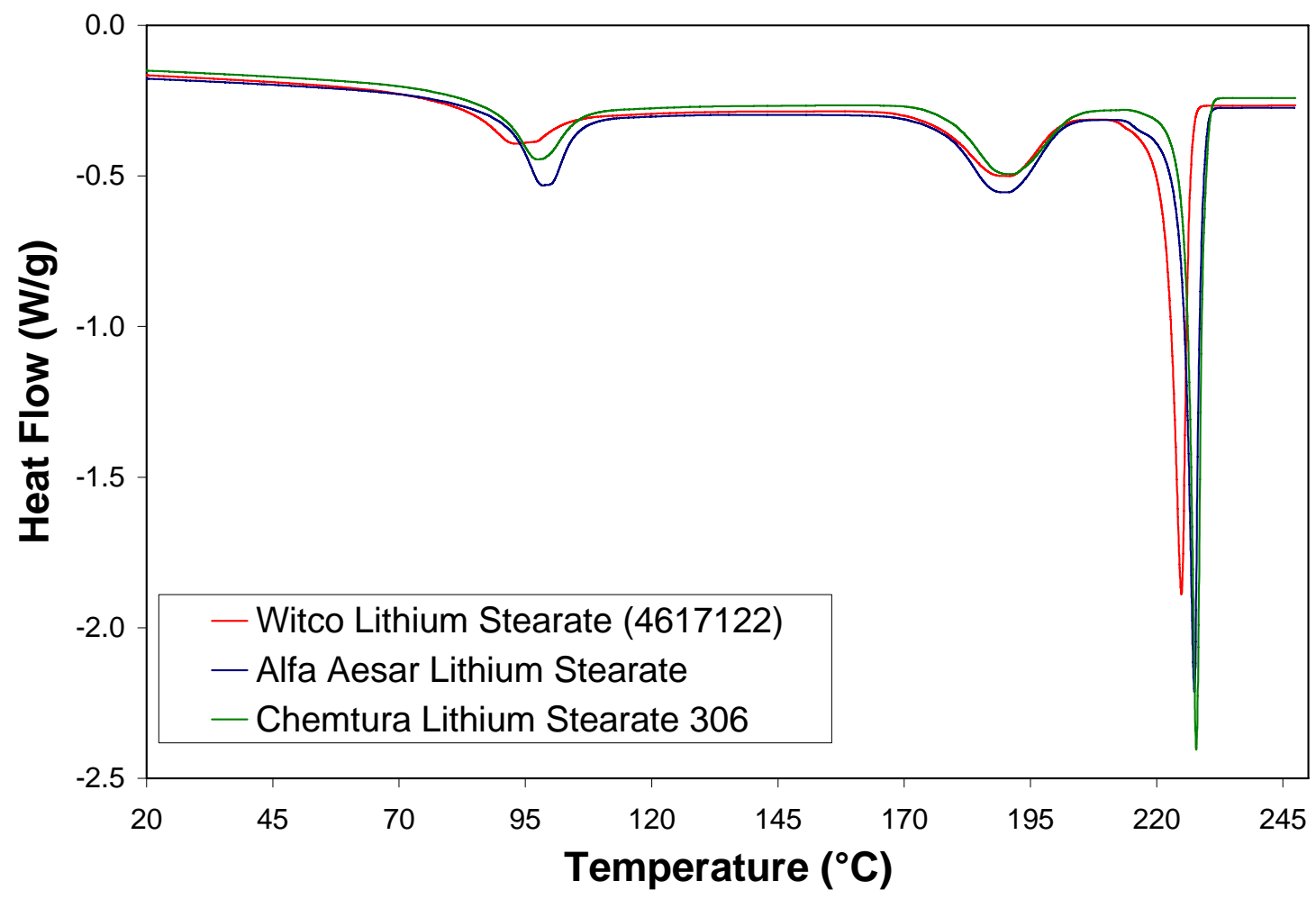

Figure 5. Second heat (reheat) DSC curves for three lots of lithium stearate.

Table 6: Peak transitions from DSC data for three lithium stearates.

\begin{tabular}{|c|c|c|c|c|c|}
\hline Vendor & Step & 1st transition & 2nd transition & 3rd transition & 4th transition \\
\hline \multirow{3}{*}{$\begin{array}{l}\text { Alfa } \\
\text { Aesar }\end{array}$} & 1st heat & $103.2^{\circ} \mathrm{C}$ & $192.0^{\circ} \mathrm{C}$ & $227.6^{\circ} \mathrm{C}$ & NA \\
\hline & cool down & $93.6^{\circ} \mathrm{C}$ & $134.4^{\circ} \mathrm{C}$ & $205.7^{\circ} \mathrm{C}$ & $218.7^{\circ} \mathrm{C}$ \\
\hline & 2nd heat & $98.6^{\circ} \mathrm{C}$ & $190.0^{\circ} \mathrm{C}$ & $227.4^{\circ} \mathrm{C}$ & NA \\
\hline & & & & & \\
\hline \multirow{3}{*}{ Chemtura } & 1st heat & $101.8^{\circ} \mathrm{C}$ & $191.9^{\circ} \mathrm{C}$ & $228.2^{\circ} \mathrm{C}$ & NA \\
\hline & cool down & $92.3^{\circ} \mathrm{C}$ & $128.8^{\circ} \mathrm{C}$ & $207.9^{\circ} \mathrm{C}$ & $219.4^{\circ} \mathrm{C}$ \\
\hline & 2nd heat & $97.5^{\circ} \mathrm{C}$ & $190.8^{\circ} \mathrm{C}$ & $227.8^{\circ} \mathrm{C}$ & NA \\
\hline \multirow{4}{*}{ Witco } & & & & & \\
\hline & 1st heat & $102.6^{\circ} \mathrm{C}$ & $192.4^{\circ} \mathrm{C}$ & $224.9^{\circ} \mathrm{C}$ & NA \\
\hline & cool down & $87.1^{\circ} \mathrm{C}$ & $131.9^{\circ} \mathrm{C}$ & $200.5^{\circ} \mathrm{C}$ & $214.4^{\circ} \mathrm{C}$ \\
\hline & 2nd heat & $93.4^{\circ} \mathrm{C}$ & $190.6^{\circ} \mathrm{C}$ & $224.9^{\circ} \mathrm{C}$ & NA \\
\hline
\end{tabular}




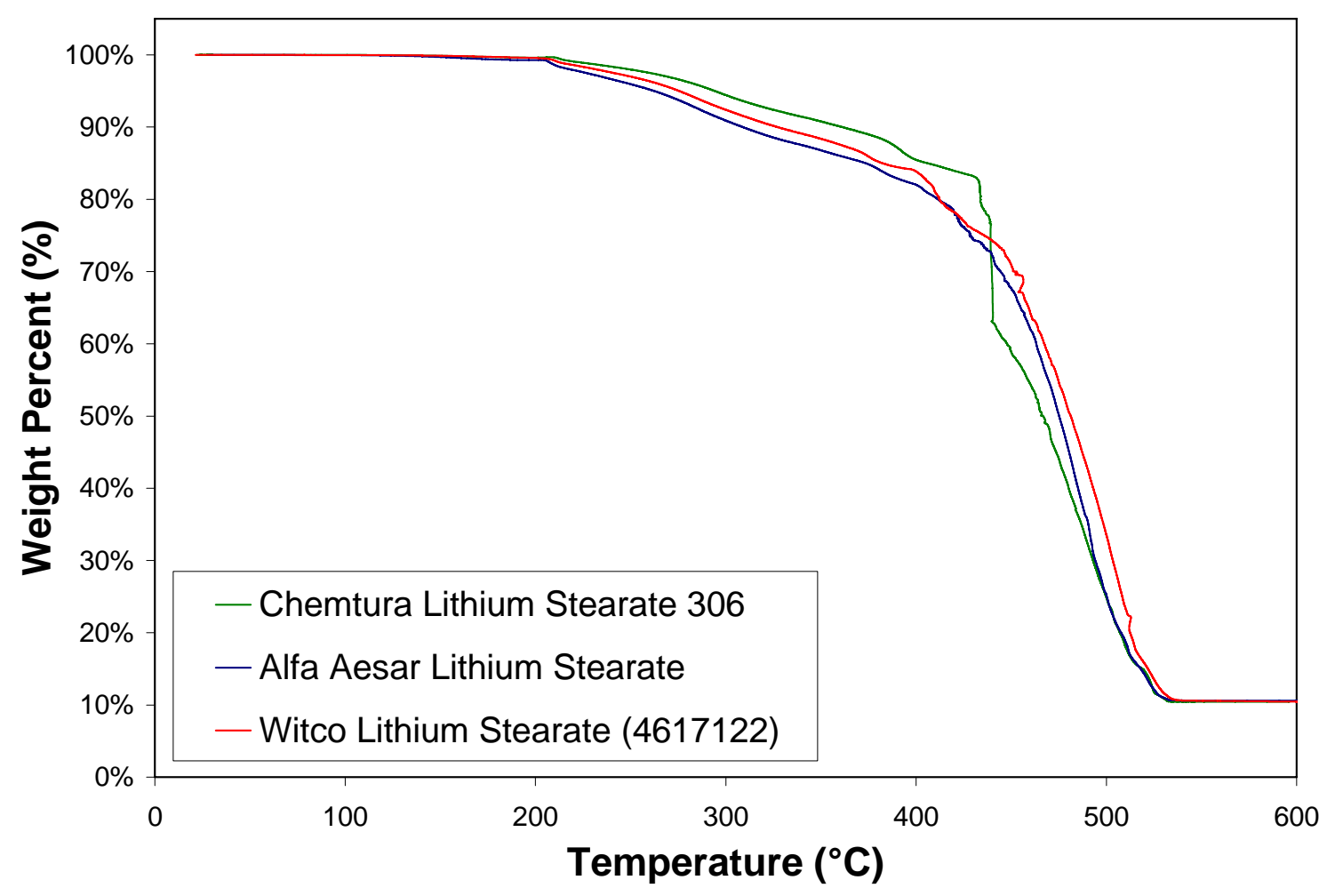

Figure 6. TGA thermograms of the three lots of lithium stearate.

\section{$\underline{\text { Discussion }}$}

The characterization data for all three lots of lithium stearates are comparable and have very little differences between them. The lithium stearates from Alfa Aesar and Chemtura (306) are both suitable replacements for the Witco lithium stearate. Lithium stearate from Alfa Aesar is available in 250-gram and 1-kilogram containers, while lithium stearate 306 from Chemtura is packaged in 25-pound bags. The smaller containers from Alfa Aesar are much more suitable for our production quantities and thus were chosen as the replacement lithium stearate.

\section{Accomplishments}

Several techniques were used to characterize the lithium stearates. Solution NMR was attempted with numerous solvents; however, the analysis could not be completed due to the limited solubility of lithium stearate. The structure of the lithium stearate was confirmed with transmission FT-IR. The FT-IR spectra for two lots of the lithium stearate showed characteristic peaks associated with carboxylate and aliphatic $\mathrm{C}-\mathrm{H}$ deformations. All three lots of lithium stearate were evaluated for moisture by Karl Fischer techniques and were found to have a very low amount of water remaining. In addition, all three lots have very similar moisture values. The thermal properties were characterized using differential scanning calorimetry and thermogravimetric analysis for the lithium stearates. Again, all three lots of lithium stearates revealed similar thermal behavior. Alfa Aesar lithium stearate was chosen as the replacement material based on the container sizes available commercially. 


\section{References}

1. E. A. Eastwood, VCE Replacement Development: Characterization of EVA Materials (Topical Report). UNCLASSIFIED. Federal Manufacturing \& Technologies: KCP-6136929, December 2004.

2. E. A. Eastwood, VCE Replacement: Curing Studies (Topical Report).

UNCLASSIFIED. Federal Manufacturing \& Technologies: KCP-613-8161, July 2006.

3. Densmore, C.; Labouriau, A.; Wingo, B.; Robison, T. “Thermal Stability Studies of VCE and TW Using a Range of Experimental Techniques,” December 2004 (LA-UR-048442).

4. Labouriau, A., Densmore, C., Meadows, K., Cordova, B., and Lewis, R., Characterization of VCE and Starting Materials: Part 1. LA-UR-06-5294. Los Alamos National Laboratory.

5. E. A. Eastwood, Characterization of Hylene MP: Curing Agent for Filled Elastomers (Topical Report). UNCLASSIFIED. Federal Manufacturing \& Technologies: KCP-6138192, September 2006.

6. E. A. Eastwood, VCE Replacement: Synthesis of VCEs with New Formulations (Topical Report). UNCLASSIFIED. Federal Manufacturing \& Technologies: KCP-613-8202, September 2006.

7. Densmore, C., Eastwood, E., Characterization of VCE and Starting Materials: Part 2. LA-UR-06-6812. Los Alamos National Laboratory.

8. P. M. Wilson, Filled VCE (Ethylene Vinyl Acetate/Vinyl Alcohol Terpolymer) Materials and Processing Handbook (Topical Report). UNCLASSIFIED. Federal Manufacturing \& Technologies: KCP-613-6051, February 1998.

9. Barbooti, M. M.; Al-Sammerrai, D. A. Journal of Thermal Analysis 1985, 30, 587-595.

10. Cronin, T.; Berry, D. Advances in Powder Metallurgy 1990, 1, 295-305.

11. Thomas, Y.; Cole, K. C.; Pelletier, S.; St-Laurent, S. Advances in Powder Metallurgy and Particulate Materials 1997, 1, 4/23-4/34.

12. Skoulios, A.; Luzzati, V. Nature 1959, 183, 1310-1312.

13. Gavrilko, T.; Drozd, M.; Puchkovskaya, G.; Naumovets, A.; Tkachenko, Z.; Viduta, L.; Baran, J.; Ratajczak, H. Journal of Molecular Structure 1998, 450, 135-139.

14. Ishchuk, Y. L.; Podlennykh, L. V.; Godun, B. A. Chemistry and Technology of Fuels and Oils 1989, 25, 53-55.

15. Ripmeester, J. A.; Dunell, B. A. Canadian Journal of Chemistry 1971, 49, 2906-2909. 


\section{Distribution}

Internal

Technical Information Center $\quad$ A56 $\quad 2 C 44 \quad 1$

E. A. Eastwood

$\mathrm{D} / 834 \quad 2 \mathrm{C} 43 \quad 2-5$

M. B. Pennington

$\mathrm{D} / 200 \quad 2 \mathrm{~B} 38 \quad 6$

E. W. Grotheer

D/834 2C43 7

T. J. Reno

D/800 MG39

8

P. J. Scheuer

D/843 FJ39

9

M. W. Trimmer

D/843

FJ39

10

\section{External}

Daniel Mendoza, LANL ORG: W-2 Mail Stop C921 11

Crystal Densmore, LANL Mail Stop J569 12

Tom Robison, LANL Mail Stop J569 13

Douglas Strack, NNSA 14

Kent Davis, KCSO 15 